\title{
Communicating Islam Nusantara through Comic
}

\author{
Alfiandi Eka ${ }^{1}$,Setyo Budi ${ }^{2}$, and Lulu Purwaningrum ${ }^{3}$ \\ \{s011808001@uns.ac.id ${ }^{1}$,setyobudi67@gmail.com²,lulu_purwaningrum@uns.ac.id $\left.{ }^{3}\right\}$ \\ ${ }^{1,2,3}$ Universitas Sebelas Maret, Surakarta. Indonesia
}

\begin{abstract}
The presence of a discourse inIslam Nusantara has triggered some polemics among Indonesian Muslims. Pros and cons have been present to address the discourse. Public-sharing has been carried out through various media to provide the right understanding of Islam Nusantara, including popular medium such as comics. The aim of this studywas to explain how a comic provides an understanding of the Islam Nusantaraconcept. Itused descriptive qualitative research method. The data were collected using literature review and interviews. The results of this study revealed that the IslamNusantaraconcept by using comics are conveyed through the narratives, illustrations (characters and symbols) made for representing the ideas, as well as the existing dialogues. The characters represent the two faces of Islam in Indonesia with the opposite model of da'wah. Some of the icons and symbols presented in the comics show the da'wah model of Islam Nusantara that can be acculturated with local cultures. Based on the analysis, it confirms that comics can be used as one of an interesting mediumto conveythe related issues. Comics, as a medium of communication, can target all communities, especially the young generation and effectively deliver messages in fun and easierway to understand.
\end{abstract}

Keywords: comics, Islam Nusantara, Indonesia, cool medium, communication

\section{INTRODUCTION}

Islam Nusantara can be regarded as the antithesis of the idea of Islam that is oriented towards Middle East or International countries. Although the discourse of Islam Nusantarabecomes a discussion and polemic among societies, pros and cons still occur. Those who contradict say that Islam is one, and no Islam that is labeled with the term of Nusantara or others.

Islam Nusantara as a discourse of thought has emerged as the theme in the $33^{\text {rd }}$ Nahdatul Ulama (NU) Major Congress held in Jombang Regency, East Java Province, Indonesia on August 1-5, 2015. The congress arose the theme "Upholding Islam Nusantara for Indonesia and World Civilization"[1].According to K.H. Said Aqil Siradj, Islam Nusantara is meant to refer to the thought that is based on the history of Islam that entered Indonesia without going through war, yet compromise on culture. He further explained that Islam Nusantara is not a new sect nor to be intended to change the Islamic doctrine[2]. 
Therefore, if this is viewed from anthropological and sociological perspectives, Islam Nusantara can be interpreted as Islam that has been understood, practiced and then internalized in the lives of Indonesian people. In the geographical context it can be interpreted as Islam of archipelago. The area of Nusantara can refer to the current territory of Indonesia[2].

The discourse of Islam Nusantara continues to develop through public-sharing by using various popular media, one of them is comics. As a popular form of arts[3], comics are considered more acceptable by the young generation[4]. It can function as messengers and have the power to dramatize an idea through images sequentially arranged and sequential arts[5][6].Also, comics have the potential to become a tool in shaping society perceptions[5]who engage in creative creation or reading and to transform attitudes, awareness, and behavior around social issues[7].

Comics are form of communication activities[8][9]. The authors can develop their ideas so that the readers will easily understand and take notes about the ideas[9][10][11].For example Panji Koming strip comics which communicate moral messages and Javanese cultural values[12] andsome local Indonesian comicswhich are used as medium of $d a^{\prime} w a h$ [13].

A comic of Islam Nusantara by Aji Prasetyo has been created to provide an understanding on the Islam Nusantara concept. This also tries to straighten out the misunderstanding that is developing in Indonesian people regarding the term of Islam Nusantara. This study focused on finding out how the author builds the communication regarding the understanding of Islam Nusantara.

\section{METHOD}

This study used a qualitative descriptive research. Data collection was done using literature review and completed with interviews. The data were then collected by searching for several books and scientific articles as the references related to the comic. Furthermore, the collected data were reduced by sorting the data that would be used and organizing the data in such a way that final conclusions can be taken.

This study usedMcLuhan's research on "hot" versus "cool" media as a theoreticalbase[14]. Based on that research comic can be represent cool communication media[15] that are high in participation. Because in comics communication receivers must "fill in," or use their imaginations to complete the communication[4].

\section{RESULT AND DISCUSSION}

The idea of Islam Nusantara has actually been shared through various media and forums, either in academic forums or formal and digital mass media. However, the lack of reading culture in Indonesian society [15] has caused the sharing to be less effective. Aji Prasetyo, a comic author, who is also Nahdliyin (NU member), feels that public-sharing using comic is an interesting strategy to provide the understanding of Islam Nusantara. According to him, comics are considered more effective since they are interesting media and can reach various communities.

The idea conveyed in this comic story reflects local genius or local wisdom, i.e. the idea that the basic idea of receiving something from the outside is more influenced by conformity with local culture. The local concepts are of no exception to be used as the basis for the entry of something from the outside, including Islam. 


\subsection{Da'wah (Preaching) Model Performed in Islam Nusantara Comic}

The story built in this comic revolves around two models of Islamic tradition in Indonesia. The first one is described as a bearded character wearing clothes identical to foreigners from the Middle East region. This character accepts rejection from the nativesof Indonesia because of its formalistic model of da'wah.

In contrast, one more character appears that is described with a character with mustache and wears a blangkon (Figure 1. (right)). The character who is then called "Kanjeng Sunan" [16] has been then told to be more accepted by the native people of Indonesian archipelago. Using a cultural approach and acculturation with local culture, such character can gradually be accepted in Islamic da'wah in Indonesian archipelago (Nusantara). This can be seen from many groups of people who are interested and accept the idea of the $d a$ ' $w a h$. This shows that in religious $d a^{\prime} w a h$, especially Islam, the use of original idioms can attract and touch the hearts of the native people.

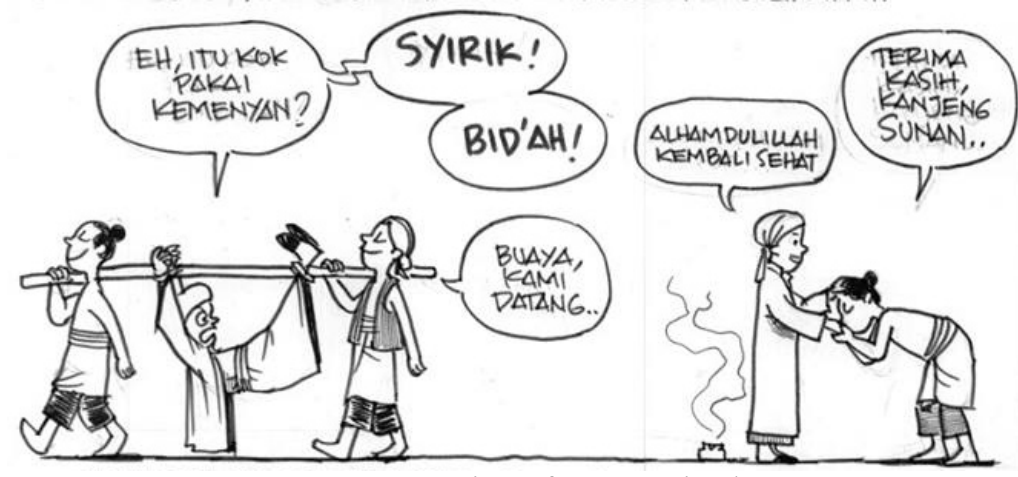

Figure 1. Comparasion of two comic character

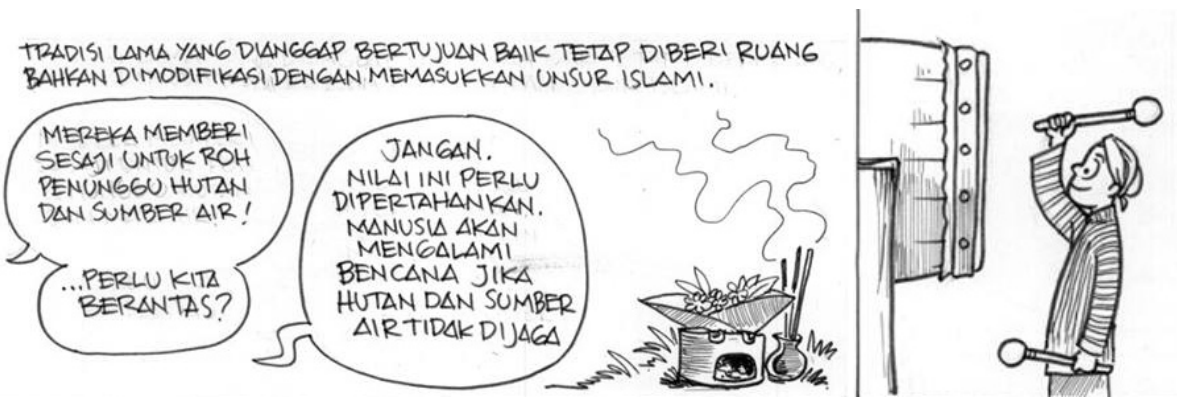

Figure 2. Sesaji (offerings)and Bedugas a acculturation symbol with local cultures

In figure 2 author shows the example of the acculturation form in several symbols. The presence of sesaji and bedug which has been considered to be a good purposeis still maintained by traditional Islamic people by entering the elements of Islam first, and modifying the values therein.

Sesaji, which was originally used for offerings to the spirits guarding the forest and water sources, has now been shifted in value to become a symbol to protect nature from the occurrence of any disasters[17]. Likewise with the use of bedug beaten before the adzan or 
Islamic call to pray, things like this are not found in Saudi Arabia. Those who receive the da'wah model are then better known as Traditional Islam[18]which today is known as Islam Nusantara.

\subsection{Concept of Nationalism in Islam Nusantara Comic}

This comic also highlights the background of the birth of the sense of nationalism in traditional Islamic people, which is told to have contributed to the independence of the Republic of Indonesia[19]. This can be seen from the historical facts shown in Figure 3. This presents the figure of Hadratus Syeh K.H. Hasyim Asy'Ari (the founder of Nahdatul Ulama) who pioneered the resolution of jihad which had been triggered the historical event in Surabaya on November 10,1945[20][21]. The fatwa was intended to give the idea that the Indonesian Archipelago or Nusantara (which at the time was shaped as the Republic of Indonesia) had no longer been oppressed by other nations (Europeans).

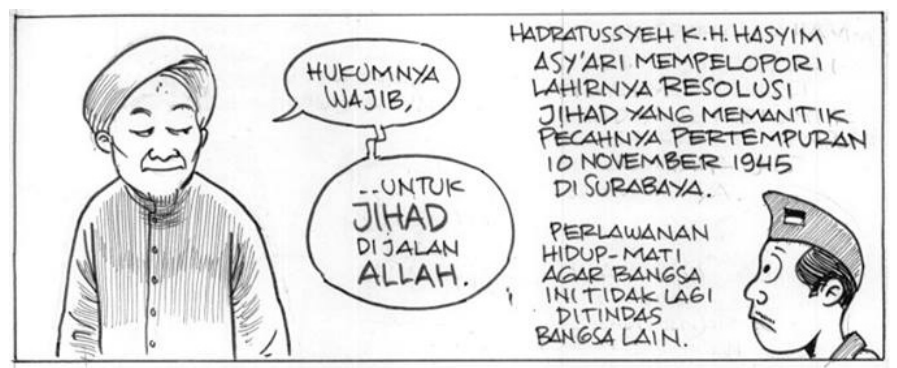

Figure 3. Hadratus Syeh K.H. Hasyim Asy'Ari character (left).

After the independence of the Republic of Indonesia until present, traditional Islamic people were described as still holding their tradition. Figure 4 depicts the people who still stay with their distinctive characteristics that are not much different from their predecessors, such as wearing blangkon, kopiah (fez), and sarong. Besides, they are also described as having a high sense of nationalism. This can be seen in figure 4 where they are having a dialogue discussing the phenomenon of Islamic preachers or called Ustadz, which in their $d a$ 'wah, they only spread the hate speech[22]. This phenomenon has been felt by traditional Islamic people to be dangerous for the integrity of the nation.

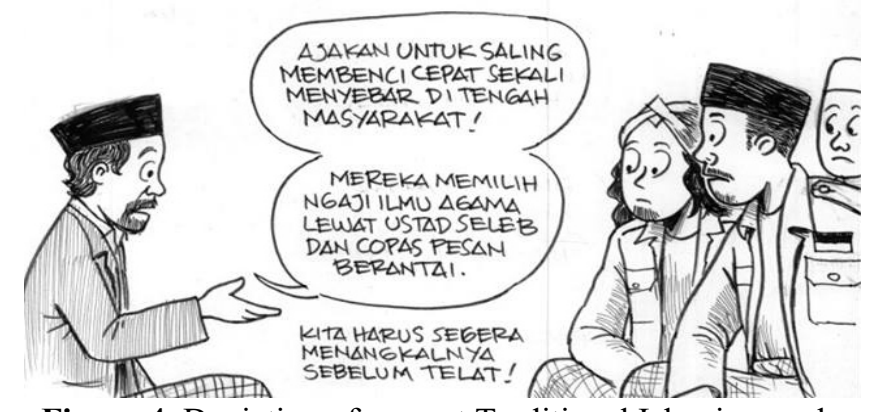

Figure 4. Depiction of present Traditional Islamic people

The depiction of Islam Nusantara can be used as a reference for comparison from other Islamic sects or movements which are based on other principles, e.g. international-oriented Islam. This is more clearly explained by the author by presenting a dialogue between an 
international-oriented Islamic figure and the author (figure 5). The author character (left) satirize the understanding of the Ustadz who is too textual to interpret the religious texts, so he is considered to misinterpret the substantial meaning of the text.

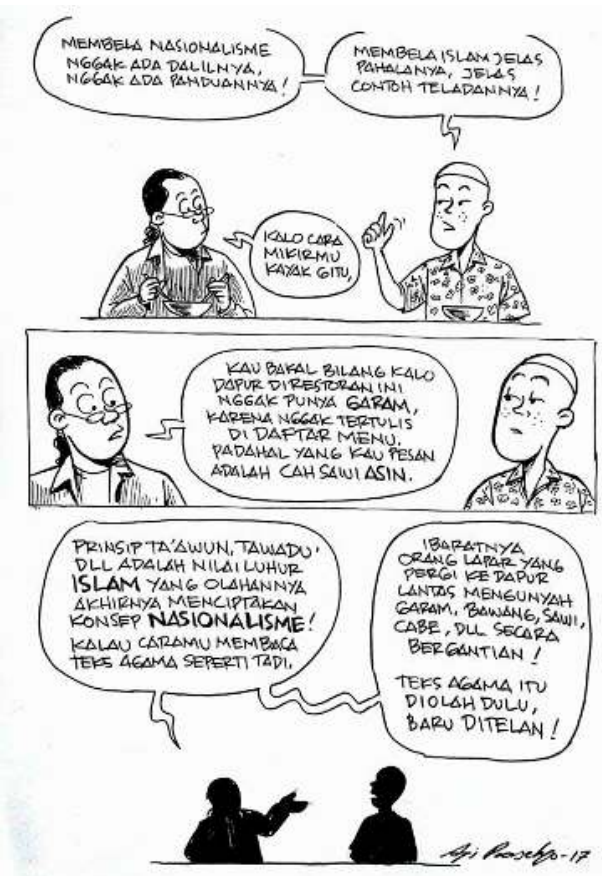

Figure 5.The character of the author (left) having a dialogue with austadzcharacter who contradicts the Islam Nusantara concept

The dialogue clearly explained that Islam Nusantara places more emphasizes on contextual Islam compared to the textual understanding. This can also be seen from the explanation of the author who put forward the concept of Ta'awun (caring for each other in the name of humanity), Tasamuh (empathy for differences), Tawadu (selflessness), and Tafahum (mutual understanding). According to the author, those concepts are the noble values of Islam which lead to the concept of nationalism [23].

The explanation above confirms that this comic provides an understanding of Islam Nusantara by conveying the concept. The disclosure of these concepts can be seen in the narratives, illustrations (characters and symbols) and the existing dialogues. Analysis of the communication addressed in the comic is slightly different from the results of the previous related journal about the Javanese cultural ethics in the Panji Koming comics. The Javanese cultural ethics in the journal can be seen from the depiction of physical movements of characters from scene to scene as well as spoken word utterances[12].Regarding the selection of comics as one of the communication media, this study is however in line with a journal that discusses comics as a mediumof $d a^{\prime}$ wahin Indonesia[13]. This also agrees with the journal stating that comics have the ability to deliver the messages since the language interpretation by pictures is easier to understand than the written and spoken languages. 


\section{CONCLUSION}

Understanding Islam Nusantara can be performed through popular media such as comics. Comics that are composed of images and writings are interesting media in disseminating or conveying certain issue. In the context of providing an understanding of the Islam Nusantara concept to the communities, especially the young generation, the selection of comics as popular media is appropriate to consider. Therefore, comics as communication media can effectively deliver messages in fun and easier way to understand.

\section{REFERENCE}

[1] D. Darmadi, "Tears and Cheers in Jombang: Some Notes on the 33rd Nahdlatul Ulama Congress," Stud. Islam., vol. 23, no. 1, 2016.

[2] A. Moqsith, "Tafsir atas lslam Nusantara ( Dari lslamisasi Nusantara Hingga Metodologi Islam Nusantara ) from the teaching of Ahlus Islam Nusantara arlt," Harmon. Jumal Multikultural Multireligius, vol. 15, no. 2, pp. 20-32, 2016.

[3] F. Text et al., "MIT Press Journals - International Journal of Learning and Media - Full Text MIT Press Journals - International Journal of Learning and Media - Full Text Are Schools Responding to Students ' Lives and 21st- - Century Learning Requirements ?,' Int. J. Learn. Media, vol. 3, no. 4, pp. 1-12, 2014.

[4] J. C. Short and T. C. Reeves, "The graphic novel: A 'Cool' format for communicating to generation Y,” Bus. Commun. Q., vol. 72, no. 4, pp. 414-430, 2009.

[5] S. McCloud, Understanding comics: The invisible art. 1993.

[6] W. Eisner, Comics \& sequential art. \{Poorhouse Press\}, 1985.

[7] E. Priego, "Comics as Research, Comics for Impact: The Case of Higher Fees, Higher Debts,” Comics Grid J. Comics Scholarsh., vol. 6, no. 1, 2016.

[8] C. M. Tribull, "Sequential Science: A Guide to Communication Through Comics," Ann. Entomol. Soc. Am., vol. 110, no. 5, pp. 457-466, 2017.

[9] F. D. Patricia, “Analisis Semiotika Komunikasi Visual Buku 'Memahami Komik' Scott McCloud,” J. Stud. Komun. (Indonesian J. Commun. Stud., vol. 2, no. 2, pp. 278-289, 2018.

[10] J. I. Rodríguez-Vázquez, Francisca-María; Aguaded, "USING COMICS AS A STRATEGY FOR LEARNING INTERCULTURAL VALUES Parole chiave," Issn 2038-3002, vol. 7, no. 1, pp. 19-31, 2016.

[11] A. Negrete, "Constructing a Comic to Communicate Scientific Information about Sustainable Development and Natural Resources in Mexico," Procedia - Soc. Behav. Sci., vol. 103, pp. 200-209, 2013.

[12] I. Ismail, H. Nugroho, and G. R. L. L. Simatupang, "Representasi Etika Budaya Jawa Dalam Komik Panji Koming: Perspektif Pendidikan Islam," El-HARAKAH (TERAKREDITASI), vol. 17, no. 2, p. 182, 2016.

[13] A. R. Yani and S. Syarifah, "Key Knowledge Generation Comic as a Medium for Da , wah in Indonesia COMIC AS A MEDIUM FOR DA ' WAH IN INDONESIA," Int. J. Humanit. Arts Soc. Sci., vol. 3, no. 2, pp. 71-77, 2017.

[14] N. Friesen, "Marshaling McLuhan for Media Theory," ESC English Stud. Canada, vol. 36, no. 2-3, pp. 5-9, 2012.

[15] H. Chute and P. Jagoda, "Special Issue: Comics \& Media," Crit. Inq., vol. 40, no. 3, pp. $1-10,2014$.

[16] Sulanam, "From Sufi Order Ritual to Indonesian Islam,” J. Indones. Islam, vol. 7, no. 1, 
p. 212, 2013.

[17] S. Indrahti, S. Maziyah, and A. Alamsyah, "Ragam Kuliner Sesaji Dalam Upacara Tradisi di Kabupaten Jepara," J. Sej. Citra Lekha, vol. 2, no. 1, p. 61, 2017.

[18] M. L. Fauzi, "The Roles of Kyai and Pesantren in Preserving Islamic Tradition and Negotiating Modernity Muhammad Latif Fauzi IAIN Surakarta - Indonesia,” J. Indones. Islam, vol. 06, no. 01, pp. 125-144, 2012.

[19] A. Farih, "Nahdlatul Ulama ( $\mathrm{Nu}$ ) Dan Kontribusinya Dalam Memperjuangkan Kemerdekaan Dan Mempertahankan Negara Kesatuan Republik Indonesia (Nkri)," Walisongo J. Penelit. Sos. Keagamaan, vol. 24, no. 2, p. 251, 2017.

[20] A. Baso, K. N. H. A. Sunyoto, and R. M. Zionis, K.H. Hasyim Asy'ari, pengabdian seorang kyai untuk negeri. 2017.

[21] Z. Darojat, "Rational Jihad: Measuring Rationality of Jihad Resolution," in International Conference on Culture and Language in Southeast Asia (ICCLAS 2017), 2017.

[22] A. Muzakki, "the Roots, Strategies, and Popular Perception of Islamic Radicalism in Indonesia," J. Indones. Islam, vol. 8, no. 1, p. 1, 2015.

[23] K. Saddhono, N. E. Wardani, and C. Ulya. "Sociopragmatic approach on discourse structure of friday prayer's sermon in java and madura island." J. of Lang and Lit, vol. 6 no. 1 pp 26-29, 2015 